Pemikiran Pendidikan Islam ... (Mohamad Ali)

\title{
PEMIKIRAN PENDIDIKAN ISLAM AHMAD SYAFII MAARIF
}

\author{
Mohamad Ali \\ Prodi Pendidikan Agama Islam dan Magister Pendidikan Islam \\ Universitas Muhammadiyah Surakarta \\ E-Mail:ma122@ums.ac.id
}

\begin{abstract}
The Indonesian Islamic intellectualism is increasingly dynamic and accounted in the global arena. This perception occurs because on the one hand, Indonesia is the largest concentration of Muslim population in the world, and on the other side there is an ontentic, dynamic and inclusive process of Islamic intellectualism. The 1980s Indonesian Islam gave birth to a series of "new intellectuals" whose ideas contributed significantly to embroidering the Indonesian pillars of social progress and justice: the Islamization, nationalism, humanity and modernity. One of the pioneers of new intellectualism worth taking into account is Ahmad Syafii Maarif. He is widely known as an Islamic thinker as well as a social activist involved in solving national and humanitarian issues. So far, the public recognizes Buya Syafii as a Muslim historian and intellectual who devotes his enormous intellectual energy to builds an inclusive Islamic culture. Beyond, there is one dimension of Buya Syafii's idea that is almost oblivious to the public's attention, namely the spark of his thoughts on Islamic education which is driven concern over the social reality of Islamic education which is dichotomous, backward, and poor in thought. The thought of Buya Syafii is intended to find a way out of the crisis of Islamic education from the "trap" of history, namely by redialog with the Qur'an. Hypothetically, Islamic education thought he borrowed, patterned religious-critical.
\end{abstract}

Keywords: Ahmad Syafii Maarif, Islamic education, critical-religious.

Abstrak: Geliat intelektualisme Islam Indonesia semakin dinamis dan diperhitungkan di kancah global. Persepsi ini terjadi karena di satu sisi, Indonesia merupakan tempat konsentrasi penduduk Muslim terbesar di dunia, dan di sisi lain ada proses pertumbuhan intelektualisme Islam yang ontentik, dinamis dan inklusif. Dekade 1980-an Islam Indonesia melahirkan sederet "intelektual baru" yang ide-idenya berkontribusi signifikan dalam menyulam pilar-pilar Indonesia berkemajuan dan berkeadilan sosial, yaitu: ke-Islaman, kebangsaan, kemanusiaan, dan kemodernan. Salah satu pelopor intelektualisme baru yang layak diperhitungkan adalah Ahmad Syafii Maarif. Dia dikenal luas sebagai pemikir Islam sekaligus aktivis sosial yang terlibat dalam upaya pemecahan persoalan kebangsaan dan kemanusiaan. Sejauh ini, publik mengenal sosok Buya Syafii sebagai seorang sejarawan dan cendekiawan Muslim yang mencurahkan energi intelektualnya yang begitu besar untuk membangun kultur Islam inklusif. Di luar itu, ada satu dimensi pemikiran Buya Syafii yang hampir luput dari perhatian publik, yaitu percikan pemikirannya tentang pendidikan Islam yang digerakkan keprihatinan atas realitas sosial pendidikan Islam yang dikotomik, terbelakang, dan miskin pemikiran. Pemikiran Buya Syafii ditujukan untuk mencari jalan keluar atas kemelut pendidikan Islam dari "jebakan" sejarah, yakni dengan mendialogkannya kembali dengan Al-Qur'an. Secara hipotetik, pemikiran pendidikan Islam yang diusungnya bercorak kritis-religius.

Kata Kunci: Ahmad Syafii Maarif, pendidikan Islam, kritis-religius. 


\section{PENDAHULUAN}

Pandangan para pengkaji Islam dalam memotret wajah Islam Indonesia telah mengalami pergeseran. Sampai paruh awal abad ke-20, Indonesia dianggap sebagai kawasan yang terbelakang dalam diskursus pemikiran Islam global. Akan tetapi, akhirakhir ini kawasan ini dipandang memiliki prospek yang cerah dan unik sebagai salah satu kiblat pemikiran dunia Islam. Dalam waktu cukup lama, para pengkaji Islam cenderung mengabaikan Islam Indonesia dalam diskurus pemikiran Islam, karena kawasan ini dianggap berada di luar pusaran arus pemikiran Islam, sehingga masih perlu mendapat perhatian tersendiri. Namun demikian, kala melontarkan penilaian itu, baik Rahman ${ }^{1}$ maupun Smith ${ }^{2}$ juga menyisipkan titik-titik kelebihan Islam Indonesia yang menurutnya berpotensi besar untuk memberi arah perubahan (transetter) terhadap situasi dunia Islam pada umumnya.

1 Fazlur Rahman menilai bahwa: "Umumnya, dalam perbincangan-perbincangan umum tentang Islam, apalagi dalam pembahasan bidang-bidang khusus seperti hukum dan pendidikan Islam, Indonesia sangat diabaikan, walaupun negeri ini negeri Muslim yang paling banyak penduduknya. Ini disebabkan adanya kesan umum bahwa Indonesia adalah kawasan Islam yang berada di luar arus pemikiran intelektual". Sedikit catatan, versi asli bahasa Inggris buku Islam and Modernity dipublikasikan 1982, sedangkan terjemahan bahasa Indonesia dipublikasikan pertama kali tahun 1985, cetakan kedua tahun 2000, dan cetakan ketiga tahun 2005. Lihat, Fazlur Rahman. 2005. Islam dan Modernitas: Tentang Transformasi Inteletual. Terjemahan Mohammad Ahsin. Bandung: Pustaka, hlm. 150.

2 W.C. Smith dalam bukunya berjudul Islam in Modern History mencatat bahwa: "Dalam hal Indonesia..., terdapat kekurangan perhatian yang menyedihkan dari pihak sarjana Barat dan juga yang lebih menakjubkan dari pihak Muslimin dari masing-masing wilayah. Peranan Islam di Indonesia dewasa ini dan peranan Indonesia dalam Islam waktu ini tak hanya, tak hanya masih harus dinilai, akan tetapi masih juga harus dicatat" (ejaan diubahan dan sesuaikan dengan ejaan terbaru bahasa Indonesia-pen.). Perlu dicatat buku itu dalam bahasa Inggris dipublikasikan 1959 dan terjemahan bahasa Indonesia diterbitkan tahun 1964. Untuk membaca lebih mendalam perkembangan dunia Islam pada periode awal modernisasi lihat, W.C. Smith. 1964. Islam dalam Sejarah Modern. Terjemahan Abusalamah. Jakarta: Bhratara, hlm.400.
"Di masa-masa akhir ini telah terjadi kegiatan intelektual tingkat tinggi di Indonesia" ${ }^{3}$, tandas Rahman. Senada dengan penilaian itu, Smith juga memandang bahwa "dari sudut Islam di sana terdapat sesuatu yang istimewa yang menarik dan potensial amat kaya"4. Benih-benih intelektualisme Islam sebagaimana ditengerai oleh Rahman, maupun sesuatu yang istimewa dalam penilaian Smith, terus tumbuh dan semakin matang seiring perluasan akses pendidikan bagi kaum santri, pertumbuhan kelas menengah Muslim yang semakin membengkak, dan kemudahan arus informasi maupun transportasi global yang melahirkan wawasan ke-Islaman yang kosmopolit.

Menurut penglihatan Nurcholish Madjid, seorang penarik gerbang gerakan pembaharuan Islam di Indonesia di era 1970/1980-an, yang kebetulan tunggal guru dengan Ahmad Syafii Maarif ketika nyantri pada Fazlur Rahman, dewasa ini Islam Indonesia tengah bergerak dari kawasan pinggiran bergeser menjadi pusat dunia Islam ${ }^{5}$. Hal ini terjadi karena Islam Indonesia terus tumbuh secara kualitatif ke arah perluasan peradaban santri ${ }^{6}$, terjadi fenomena proses santrinisasi, dimana telah lahir santri baru yang canggih tanpa rasa canggung turut mengambil peran dalam kehidupan kebangsaan. Di sebelah lain, kesantrian atau keislamannya itu bukan berwatak ekstrim dan eksklusif, tapi berwatak moderat atau washathiyah yang secara distingtif memiliki corak yang berbeda dengan Islam yang berkembang di kawasan Arab. Pemahaman Islam yang moderat, tengahan, washathiyah inilah

3 Fazlur Rahman. Islam ...hlm. 150.

4 W.C. Smith. Islam.... hlm. 400.

5 Nurcholish Madjid. 2000. "Islam in Indonesia: A move from the periphery to the center" dlm. Kultur. Vol. 1/ No. 1, hlm. $1-16$.

6 Harry J. Benda, sebagaimana dipertajam kembali oleh Boland menandaskan bahwa: "Sejarah Islam di Indonesia adalah sejarah peradaban yang sedang berkembang meluas, serta dampaknya terhadap kehidupan keagamaan, sosial, dan politik Indonesia. Lihat, B.J. Boland. 1985. Pergumulan Islam di Indonesia. Terjemahan Saafroedin Bahar. Jakarta: Grafiti Pers, hlm. 6. 
yang layak disumbangkan ke dunia Islam internasional ${ }^{7}$.

Cendekiawan Muslim yang sejarawan sekaligus budayawan, Kuntowijoyo berpandangan bahwa memasuki dekade 1980-an kesadaran beragama umat Islam Indonesia mulai bergeser dari tahap berpikir ideologis ke arah berpikir keilmuan, atau periode ide ${ }^{8}$. Dalam periode ide, Islam dipahami dalam kerangka ilmu, ajaran agama dirumuskan atau ditafsirkan menjadi seperangkat teori untuk kemudian dijadikan kerangka aksi, sebagai landasan untuk bertindak.

Geliat intelektualisme Islam Indonesia kontemporer dalam menggumuli masalahmasalah kebangsaan, kemanusiaan, dan kemoderenan telah menarik perhatian peneliti luar maupun dalam negeri untuk mengkajinya. B. J. Boland ${ }^{9}$, Greg Barton ${ }^{10}$, Muhammad Kamal Hassan ${ }^{11}$, untuk menyebut beberapa nama yang karyanya cukup popular. Sementara itu, peneliti dari dalam terdapat sejumlah nama yang cukup terkenal, seperti: Fachry Ali dan Bahtiar Effendi ${ }^{12}$, Din Syamsuddin ${ }^{13}$, Ahmad Syafii Maarif ${ }^{14}$, M. Syafii Anwar ${ }^{15}$, dan Bahtiar Effendy ${ }^{16}$, dan M. Rusli

$7 \quad$ Azumardi Azra. 2010. "Islam Indonesia: Kontribusi kepada Peradaban Global”, dlm. Prisma Vol. 29, Oktober 2010, hlm. 83-91.

8 Kuntowijoyo. 1994. Dinamika Umat Islam di Indonesia. Yogyakarta: Salahuddin Press \& Pustaka Pelajar, hlm. 29-49.

9 B. J. Boland. 1985. Pergumulan Islam di Indonesia 1945-1970. Terjemahan Saafroeddin Bahar. Jakarta: Grafiti Pers.

10 Greg Barton. 1999. Gagasan Islam Liberal di Indonesia. Terjemahan Nanang Tahqiq. Jakarta: Pustaka Antara-Paramadina.

11 Muhammad Kamal Hassan. 1987. Modernisasi Indonesia: Respon Cendekiawan Muslim. Terjemahan Ahmadie Thaha. Jakarta: Lingkaran Studi Indonesia.

12 Fachry Ali \& Bahtiar Effendy. 1986. Merambah Jalan Baru Islam: Rekonstruksi Pemikiran Islam Indonesia Masa Orde Baru. Bandung: Mizan.

13 Din Syamsuddin. 2001. Islam dan Politik Era Orde Baru. Jakarta: Logos.

14 Ahmad Syafii Maarif. 2006. Islam dan Pancasila sebagai Dasar Negara. Jakarta: LP3ES.

15 M. Syafii Anwar. 1995. Pemikiran dan Aksi Islam Indonesia. Jakarta: Paramadina.

16 Bahtiar Effendy. 1998. Islam dan Negara: Transformasi Pemikiran dan Praktik Politik Islam di Indonesia. Jakarta: Paramadina.
Karim $^{17}$. Dari paparan karya-karya tersebut dapat diketahui bahwa pemikiran politik Islam Indonesia paling banyak menyedot perhatian peneliti.

Di sebelah lain, pemikiran kependidikan Islam belum tersentuh sama sekali. Padahal, beberapa intelektual yang diteliti itu juga memiliki perhatian dan karya tentang pendidikan ${ }^{18}$. Terabaikannya diskursus kependidikan bisa jadi karena dianggap tidak menantang atau dianggap kurang seksi dibanding masalah politik maupun ekonomi. Padahal, sesungguhnya perbincangan tentang pemikiran pendidikan tidak kalah strategis, sebab ia berurusan dengan penyiapan generasi baru yang akan berkiprah di masa depan. Warna generasi masa depan ditentukan oleh corak pemikiran dan praktik pendidikan yang tengah berjalan saat ini.

Di tengah kelangkaan kajian pemikiran pendidikan Islam, melalui tulisan ini penulis ingin berkenalan dan berdialog dengan Buya Syafii untuk memperbincangkan problematika, isu-isu aktual, dan berbagai upaya pemecahan yang bisa dilakukan untuk mengatasi kemelut pendidikan Islam. Untuk melakukan hal itu, penulis berupaya melacak data-data, mendeskripsikan dan merekonstruksi percikan pemikiran pendidikan Islam Buya Syafii. Sebagaimana ditandaskan di atas,

17 M. Rusli Karim. 1985. Dinamika Islam di Indonesia: Suatu Tinjauan Sosial Politik. Yogyakarta: Hanindita.

18 Dua tokoh penting penggerak pemikiran Islam Indonesia dekade 1980-an, Abdurrahman Wahid dan Nurcholish Madjid, telah meluncurkan percikan pemikiran pendidikannya dalam bentuk buku tersendiri. Lihat, Nurcholish Madjid. 1997. Bilikbilik Pesantren: Sebuah Potret Perjalanan. Jakarta: Paramadina, yang membicarakan kondisi ideal bagi pesantren, kiprah pesantren, dan masalah-masalah yang dihadapi pesantren. Sementara itu, Abdurrahman Wahid. 2007. Menggerakkan Tradisi: Esai-esai Pesantren. Yogyakarta: LKiS, merangkum hampir seluruh tulisannya tentang pendidikan Islam. Yang menarik, kedua intelektual ini mengapresiasi peran kesejarahan dan kultur pendidikan pesantren sambil menyuarakan kritiknya agar pesantren bergerak lebih dinamis dan akomodatif terhadap perkembangan ilmu dan teknologi modern. Sayangnya, sejauh ini percikan pemikiran pendidikan Islam Buya Syafii belum dikumpulkan menjadi buku tersendiri, tulisantulisan tentang pendidikan Islam masih berserakan di berbagai buku secara terpisah. 
kajian tentang pemikiran pendidikan Islam di Indonesia relatif terabaikan. Oleh karena itu, suatu kajian pemikiran seorang tokoh pendidikan Islam tentu sangat bermakna untuk menghidupkan wacana pemikiran pemikiran kependidikan Islam.

Sejauh ini penulis belum menemukan suatu tulisan dalam bentuk buku yang secara khusus mengkaji pemikiran pendidikan Buya Syafiii ${ }^{19}$. Oleh karena itu, untuk menjajagi pemikiran pendidikan Islam Ahmad Syafii Maarif diperlukan tinjauan secara umum tentang corak pemikiran ke-Islaman yang diusungnya. Dengan memahami corak pemikiran ke-Islaman yang dikembangkannya, diharapkan lebih memudahkan untuk memasuki kawasan pemikiran kependidikannya. Karena, pada umumnya hubungan antara paham agama dan produk pemikiran yang dihasilkanya relative berdekatan.

Fachry Ali dan Bahtiar Effendi menyebut pemikiran ke-Islaman Buya Syafii bercorak Modernisme Islam, sebuah corak pemikiran yang berakar kuat pada kaum modernis awal (baca: Muhammadiyah dan Masyumi), tetapi dalam beberapa hal, justru melampauinya . Perhatian utama Buya Syafii tercurah pada proses pelembagaan Islam dari sudut sejarah dan pemikiran berpapasan dengan modernisasi

19 Beberapa buku yang membicarakan pemikiran tokohtokoh pendidikan Islam tidak ada satupun yang membahas Ahmad Syafii Maarif. Lihat: Abuddin Nata. 2003. Pemikiran Para Tokoh Pendidikan Islam. Jakarta: Rajawali Pers; Ruswan Thoyib dan Darmuin (Ed.). 1999. Pemikiran Pendidikan Islam: Kajian Tokoh Klasik dan Kontemporer. Yogyakarta: Pustaka Pelajar; Abuddin Nata. 2005. Tokoh-tokoh Pembaharuan Pendidikan Islam di Indonesia, Jakarta: Rajawali Pers. Namun ada sebuah komentar pendek dari Azra, mantan Rektor UIN Jakarta, yang menarik untuk dikutip di sini: "Masih berkenaan dengan pola kajian pemikiran dan konsepsi ini menarik untuk menyinggung tentang kemunculan diskursus kritis tentang pendidikan Islam dalam konteks perkembangan mutakhir dalam dunia pendidikan Barat pada umumnya. Hal ini misalnya terlihat dalam antologi kecil berjudul sederhana Pendidikan Islam di Indonesia: Antara Cita dan Fakta. Meski buku ini relative kecil, tetapi ia mencakup artikel-artikel yang "thought provoking", misalnya, tulisan A. Syafii Maarif: "Pendidikan Islam sebagai Paradigma Pembebasan”...... Azumardi Azra. 1999. Pendidikan Islam: Tradisi dan Modernisasi Menuju Milenium Baru. Jakarta: Logos, hlm. 93 dan perubahan-perubahan sosial-ekonami dan politik yang begitu cepat ${ }^{20}$. Sementara itu, M. Syafii Anwar menggolongkan pemikiran Buya Syafii berhaluan Idealistik, yaitu suatu pemikiran yang bertolak dari pandangan pentingnya perjuangan umat untuk berorientasi pada tahapan menuju Islam cita-cita (ideal Islam) ${ }^{21}$. Dari dua penelitian itu, dapat diketahui bahwa telaah atas pemikiran Islam Buya Syafii melahirkan kesimpulan yang berlainan, di satu sisi menyebut "Modernisme Islam", dan "Ideal Islam" di sisi lain. Meski sepintas menghasilkan kesimpulan berbeda, tetapi tipologi ini dapat membantu sebagai kerangka referensi untuk menelaah lebih jauh corak pemikiran kependidikan yang dikembangkannya.

Secara garis besar, telaah terhadap permasalahan pendidikan dapat dibedakan menjadi tiga wilayah permasalahan, yaitu: masalah-masalah landasan pendidikan (foundational problems of education), masalah-masalah struktur lembaga pendidikan (structural problems of educational institution), dan masalahmasalah operasional pendidikan (operasional problems of education) ${ }^{22}$. Sementara itu, Crow dan Crow membedakan masalah atau pembahasan ilmu pendidikan menjadi tiga, yaitu: teori pendidikan, praktik pendidikan, dan penelitian bagi pengembangan ilmu dan terapan pendidikan ${ }^{23}$. Berdasarkan

20 Fachry Ali dan Bahtiar Effendy. 1988. Merambah Jalan .... hlm. 278.

21 M. Syafii Anwar. 1995. Pemikiran dan.... hlm. 178.

22 Masalah-masalah landasan pendidikan ialah keseluruhan masalah yang mendasari segenap praktik pendidikan yang kita laksanakan dan mendasari segenap struktur lembaga pendidikan yang kita bangun untuk melaksanakan tindakantindakan pendidikan. Masalah-masalah struktur lembaga pendidikan adalah keseluruhan masalah yang berhubungan dengan struktur lembaga yang kita perhitungkan untuk melaksanakan tindakan pendidikan. Masalah-masalah operasional pendidikan ialah keseluruhan masalah tentang cara melaksanakan tindakan pendidikan, baik dalam lingkungan keluarga, sekolah, maupun masyarakat. Untuk memahami lebih rinci tipologi permasalahan pendidikan, lihat, Mochtar Buchori. 1994. Spektrum Problematika Pendidikan di Indonesia. Yogyakarta: Tiara Wacana, hlm. 179-184.

23 Crow and Crow. 1990. Pengantar Ilmu Pendidikan. 
pemetaan permasalahan pendidikan dua pakar tersebut, dapat diketahui bahwa kajian tentang pemikiran pendidikan Islam Buya Syafii merupakan diskursus dalam tentang landasan dan, atau teori pendidikan.

Dalam penelitian kependidikan, umumnya persoalan landasan, ataupun teori pendidikan, merupakan kajian yang terlantar dan sangat jarang dilakukan oleh para peneliti ${ }^{24}$. Realitas ini sungguh memprihatinkan, sebab, pembahasan tentang landasan ataupun teori pendidikan justru dapat memberi arah terhadap praktik dan struktur pendidikan yang benar. Keterlantaran perbincangan tentang landasan dan teori pendidikan Islam pada urutanya berdampak pada miskinnya improvisasi kelembagaan dan operasional pendidikan Islam. Keadaan ini tentu tidak menguntungkan bagi kegiatan pengembangan pendidikan Islam.

Bertitik tolak dari uraian latar belakang masalah di muka, secara sederhana permasalahan penelitian ini dapat dirumuskan sebagai berikut: (1) bagaimana pembacaan Buya Syafii terhadap permasalahan mendasar pendidikan Islam di Indonesia; (2) solusi apa yang ditawarkan Buya Syafii untuk memecahkan problematika pendidikan Islam. Sejalan dengan rumusan permasalahan tersebut, tujuan penelitian ini adalah untuk menjawab permasalahan pendidikan Islam seperti yang rumusan di atas. Ringkasnya, penelitian ini bertujuan untuk: (1) mengidentifikasi sketsa permasalahan pendidikan Islam Indonesia dalam pandangan Buya Syafii; (2) menganalisis konstruksi pemikiran pendidikan Islam Buya Syafii yang merupakan tawarannya untuk memecahkan permasalahan pendidikan Islam.

\section{METODE PENELITIAN}

Sejalan dengan permasalahan penelitian, sebagaimana telah disinggung

Yogyakarta: Rake Sarasin, hlm. v - vii.

24 Mochtar Buchori. 1994. Spektrum Problematika........ hlm. 182. di atas, maka data-data yang dibutuhkan untuk memahami dan memecahkan permasalahan penelitian adalah berupa konsep-konsep atau ide-ide yang bersifat kualitatif. Data kualitatif tidak tampil dalam bentuk angka-angka statistik, tetapi tampil dalam bentuk konsep-konsep, ideide, ataupun gagasan yang dalam hal ini lebih diutamakan konsep ataupun ide yang telah terumuskan dalam bentuk tulisan.

Sejalan dengan data-data penelitian yang bersifat kualitatif, maka metode yang digunakan untuk memecahkan masalah adalah metode penelitian kualitatif. Ringkasnya, penelitian ini berjenis kualitatif noninteraktif, disebut juga penelitian analisis, yaitu suatu jenis penelitian yang bertujuan untuk mendeskripsikan dan menganalisis pemikiran pendidikan Islam seorang tokoh, bernama Ahmad Syafii Maarif (Buya Syafii) dengan mendasarkan pada deskripsi dan analisis atas karya-karya tertulisnya (kepustakaan).

Analisis konsep dilakukan untuk menemukan konsep-konsep kunci yang menjadi simpul-simpul pemikiran kependidikannya ${ }^{25}$. Pola kajian demikian lebih menekankan pada olahan kebermaknaan secara filosofis dan teoritis, sehingga tidak memerlukan olahan uji empirik di lapangan ${ }^{26}$. Yang lebih diperlukan adalah koherensi ide-ide yang dibangun secara rasional berdasarkan sumber-sumber yang absah.

Untuk mengumpulkan data-data kualitatif yang berkaitan dengan konsepsi

25 Secara garis besar metode penelitian kualitatif dapat dibedakan dalam dua macam, kualitatif interaktif dan noninteraktif. Metode kualitatif interaktif ialah studi mendalam yang memakai teknik pengumpulan datanya diperoleh langsung dari orang (manusia) dalam lingkungan alamiahnya, yang termasuk jenis ini antara lain: studi etnografik, studi historis, studi fenomenologis, teori dasar, dan studi kasus. Metode penelitian kualitatif noninteraktif atau penelitian analisis adalah studi yang memakai teknik pengumpulan data dengan cara teknik dokumen, tidak berinteraksi secara langsung dengan orang, tetapi dengan dokumen. Untuk pembahasan lebih rinci, lihat, Nana Syaodih Sukmadinata. 2009. Metode Penelitian Pendidikan. Bandung: Rosdakarya, hlm. 60-65.

26 Kaelan. 2005. Metode Penelitian Kualitatif bidang Filsafat. Yogyakarta: Paradigma, hlm. 6. 
pendidikan Islam Buya Syafii digunakan teknik dokumen atau studi kepustakaan. Data verbal dalam bentuk tertulis disebut dokumen ${ }^{27}$ yang dalam hal ini dokumennya berupa tulisan-tulisan Buya Syafii sendiri sebagai sumber data primer, dan atau tulisan orang lain yang berkaitan atau membahas pemikiran Buya Syafii yang dalam hal ini disebut sebagai sumber atau data sekunder. Kedua jenis data ini dicari dan dilacak melalui perpustakaan, baik perpustakaan pribadi penulis, maupun perputakaan Universitas Muhammadiyah Surakarta yang memberikan kemudahan dengan menyediakan pojok Muhammadiyah (Muhammadiyah corner) yang berisi bukubuku dan jurnal tentang gerakan maupun tokoh-tokoh Muhammadiyah.

Perlu ditandaskan bahwa dalam penelitian kualitatif proses pencarian data dan analisis data berjalan beriringan. Secara teknis, proses analisis data dilakukan melalui tiga tahapan. Tahap pertama, melacak dan mengumpulkan seluruh tulisan Buya Syafii yang terentang mulai tahun 1980 hingga 2006. Dalam proses pelacakan ini tidak ditemukan suatu buku tersendiri yang berisi pemikiran pendidikan Islam Buya Syafii, tetapi ada tiga bukunya yang yang secara selintas membicarakan masalah pendidikan Islam. Ketiga buku itu adalah: Peta Bumi intelektualisme Islam di Indonesia, Independensi Muhammadiyah di Tengah Pergumulan Pemikiran Islam dan Politik, dan Islam dalam Bingkai Keindonesiaan dan Kemanusiaan: Sebuah Refleksi Sejarah. Di samping ketiga buku tersebut, masih ada dua buku antologi pendidikan Islam yang memuat tulisan Buya Syafii, yaitu: Muslih Usa dan Aden Wijdan (Ed.), Pendidikan Islam dalam Peradaban Industrial ${ }^{28}$ dan Muslih Usa (Ed.), Pendidikan Islam di Indoensia ${ }^{29}$.

27 Sartono Kartodirdjo. 1983. "Metode Penggunaan Dokumen" dlm. Kuntjoroningrat (Ed.). MetodeMetode Penelitian Masyarakat .Jakarta: Gramedia, hlm. 61-92.

28 Muslih Usa dan Aden Wijdan (Ed.) 1999. Pendidikan Islam dalam Peradaban Industrial. Yogyakarta: Aditya Media.

29 Muslih Usa (Ed). 1991. Pendidikan Islam di Indonesia:
Tahap kedua, setelah data-data terkumpul kemudian kategorisasi dan dipilih tulisan-tulisan Buya Syafii yang berbicara tentang pendidikan Islam dan tema lain, tapi masih beririsan dengan pendidikan Islam. Tahap ketiga, berupaya menemukan makna di balik konsep-konsep pendidikan Islam Buya Syafii yang sudah ditata menurut struktur pembahasan berikut: problematika pendidikan Islam dari optik Buya Syafii, dan solusi atau terobosan pemikiran pendidikan Islam yang ditawarkannya.

\section{HASIL DAN PEMBAHASAN}

Sebelum membedah pemikiran pendidikan Islam Buya Syafii, sebuah tinjauan selintas tentang lika-liku kehidupan penting dibicarakan. Namun karena sudah ada autobiografi ${ }^{30}$ yang membahas secara lengkap, makakesempataninimenyinggung dua hal: perjalanan pendidikan dan pergulatan intelektualitasnya.

Perjalanan pendidikan Buya Syafii mencerminkan pola asuh santri baru. Gambaran pola pendidikan santri tempo dulu adalah demikian: setelah mengenyam pendidikan agama di nggon ngaji dan pesantren kemudian pergi haji sekaligus belajar agama kepada ulama-ulama besar di Mekkah ${ }^{31}$. Ketika dia lahir, tanggal 31 Mei 1935 di Sumpur Kudus, Sumatra Barat, gerakan Muhammadiyah telah menembus wilayah itu. Oleh karena itu, Syafii kecil tidak pergi ke pesantren tradisional, tapi bersekolah di Madrasah Mualimin Muhammadiyah Lintau (1953) dan Madrasah Mualimin Yogyakarta (1956).

Sarjana Muda ditempuh di Universitas Cokroamnoto Surakarta (1964), dan sarjana lengkap dalam pendidikan sejarah di IKIP (Universitas Negeri) Yogyakarta (1968). Gelar MA ilmu sejarah diperoleh dari Ohio

Antara Cita dan Fakta. Yogyakarta: Tiara Wacana.

30 Ahmad Syafii Maarif. 2009. Titik-titik Kisar di Perjalananku. Bandung: Mizan.

31 James L.Peacock. 1983. Pembaharu dan Pembaharuan Agama. Terjemahan Muhadjir Darwin. Yogyakarta: Hanindita, hlm. 17. 
University (1973) dan gelar PhD dalam pemikiran Islam dari University of Chicago, Amerika Serikat (1983). Sekali lagi, berbeda dengan generasi santri sebelumnya yang belajar agama ke Mekah, Buya Syafii belajar ilmu agama di Barat-Amerika Serikat. Situasi ini tidak lepas dari pergeseran kajian Islam di Barat-Amerika yang secara metodologis di nilai lebih maju.

Pergolakan pemikiran keagamaan mengalami "pencerahan" selama perkuliahan pemikiran Islam di bawah bimbingan Fazlur Rahman. Sebelum keberangkatan studi S3 di Chicago, Buya Syafii masih menggegam cita-cita mendirikan Negara Islam. Namun setelah melalui pergolakan intelektual yang intensif, ia sampai pada sebuah kesimpulan untuk mengubur cita-cita itu, dan formulasi baru yang ditawarkan ialah bagaimana mensinergikan antara keislaman, keindonesiaan, dan kemanusiaan. Pemahaman inilah yang kemudian membingkai seluruh pemikirannya, tidak terkecuali pada aspek pendidikan Islam.

Tulisan Buya Syafii tentang pendidikan Islam seluruhnya di tulis setelah era 1980-an, setidaknya yang menjadi bahan kajian ini, paska mengalami pergolakan intelektual di Chicago. Tinjaun selintas perjalanan pendidikan dan pergeseran pemikirannya, meski jauh dari memadai, sudah dapat mengambarkan latar belakang pemikiran pendidikannya. Sekarang beralih untuk memasuki inti pembahasan. Secara garis besar dibagi menjadi dua bagian: sketsa permasalahan pendidikan Islam dan percikan pemikiran pendidikan Islam Buya Syafi. Bagian pertama mengelaborasi permasalahan dan disusul bagian kedua solusi pemikirannya.

\section{Sketsa Permasalahan Pendidikan Islam}

Dalam kacamata Buya Syafii, setidaknya terdapat tiga permasalahan krusial yang mendera dan menghadang pendidikan Islam. Ketiga permasalahan tersebut adalah: dualisme dikotomis ilmu, rendahnya mutu pendidikan Islam, dan mandeknya intelektualisme Islam. Tiga masalah ini sesungguhnya saling jalin kelindan dan bersifat interdependensi. Misalnya, ketika membahas masalah dualisme dikotomi ilmu, maka sesungguhnya itu berkaitan erat dan berakar pada kemandekan intelektualisme Islam dan rendahnya mutu pendidikan Islam. Demikian pula sebaliknya, kemandekan intelektualisme Islam merupakan akibat dari, dan pada urutanya berdampak pada rendahnya mutu pendidikan dan mendarah-dagingnya dualisme dikotomi ilmu.

Selanjutnya, untuk memberi gambaran dan ilustrasi yang lebih rinci tentang permasalahan pendidikan Islam dari optik Buya Syafii, ketiga masalah itu perlu dirinci satu persatu. Sekali lagi, meskipun dijelaskan secara terpisah, namum ketiga saling berjalin kelindan.

\section{Dualisme dikotomis ilmu}

Dalam sebuah artikel, Buya Syafii menjabarkan akar dan dampak munculnya dualisme dikotomi ilmu dalam penyelenggaraan pendidikan Islam dan pandangan hidup umat umat Islam. Menurut analisisnya, kemunculan dualisme dikotomi ilmu di kalangan umat Islam disebabkan oleh, dan berakar pada, fondasi filosofis yang rapuh, yang pada urutannya melahirkan pandangan keilmuan yang dikotomis, di mana ilmu-ilmu umum cenderung dianak-tirikan di kalangan umat Islam. Padahal, penguasaan dan eksplorasi dunia memerlukan piranti ilmu-ilmu umum.

Ringkasnya, menggejalanya dualisme dikotomi ilmu di kalangan umat Islam disebabkan oleh rapuhnya fondasi atau landasan filosofis system pendidikan Islam. Tentang rapuhnya filosofi pendidikan Islam, kerapuhan Buya Syafii berpandangan bahwa:

Kelemahan sistem pendidikan ini berakar pada kerapuhan fondasi filosofis yang mendasari sistem itu. Kerapuhan ini tercuat keluar dalam bentuk dualisme dikotomis antara apa yang dikategorikan ilmu-ilmu agama dan ilmu-ilmu-ilmu 
sekuler. Ilmu-ilmu agama menduduki posisi fardhu 'ain, sedangkan ilmu-ilmu sekuler paling tinggi berada dalam posisi fardhu kifayah. Dalam realitasnya kemudian, ilmu-ilmu umum ini menjadi terabaikan dan bahkan tercampakkan. Padahal untuk menguasai dunia ilmu-ilmu itu merupakan prasyarat yang harus dimiliki ${ }^{32}$.

Kemunculan dualisme dikotomi ilmu di samping karena rapuhnnya fondasi filosofis pendidikan Islam, juga diperuncing dan dipertajam oleh sejarah kelam kolonialisme penjajahan Barat atas negeri-negeri Muslim. Gerakan modernisme Islam muncul sebagai gerakan pembebasan negeri-negeri Muslim dari kolonialisme Barat. Gerakan pembebasan tidak melalui "pembrontakan" dan perlawanan bersenjata, tapi dengan jalan memperbaiki mutu pendidikan Islam. Buah dari gerakan ini adalah munculnya dualisme pendidikan Islam; pesantren di satu sisi, dan sekolah umum di sisi yang lain.

Pendidikan Islam sebagai warisan dari periode klasik akhir bukan lagi ditegakkan atas fondasi intelektual spiritual yang kokoh dan anggun. Diterimanya prinsip dikotomi antara ilmu-ilmu agama dan ilmu-ilmu umum adalah di antara indikasi kerapuhan dasar filosofis pendidikan Islam itu. Dikotomi itu terlihat dengan jelas pada dualisme sistem pendidikan di negerinegeri Muslim: Sistem pesantren dengan segala variasi dan implikasinya dalam pembentukan wawasan intelektual umat, dan pendidikan sekular dengan segala dampak dan akibatnya dalam persepsi keagamaan kita. Dualisme dikotomis ini kemudian diperkuat oleh sistem penjajahan Barat atas dunia Islam yang berlangsung

32 Ahmad Syafii Maarif. 1994. "Pemikiran tentang Pembaharuan Pendidikan Islam di Indonesia", awalnya sebagai diskusi di depan Forum Pascasarjana Fakultas Tarbiyah IAIN Sunan Ampel Malang, tanggal 19 Desember 1987, artikel ini kemudian di muat pada harian Masa Kini tanggal 18 Januari 1988. Tanpa mengalami perubahan artikel ini juga dimuat dalam buku antologi Muslih Usa (Ed). 1991. Pendidikan Islam di Indonesia: Antara Cita dan Fakta. Yogyakarta: Tiara Wacana, hlm. 146-155; dan Ahmad Syafii Maarif. 1994. Peta Bumi intelektualisme Islam di Indonesia. Bandung: Mizan, hlm. 149-154. cukup lama. Antara dua sistem ini hampirhampir tidak ada komunikasi pada masa lampau. Yang nampak ke permukaan adalah sikap dan budaya saling curiga dan saling mencemburui. Dengan demikian anak-anak umat bukan saja punya persepsi yang berbeda tentang agama, manusia, dan hidup, tapi persepsi itu berhadapan satu sama lain secara diametral ${ }^{33}$.

\section{Rendahanya kualitas pendidikan Islam}

Dewasa ini, Indonesia merupakan pusat konsentrasi penduduk Muslim terbesar di dunia. Dari keseluruhan penduduk yang berjumlah 250 juta, hampir 90\% memeluk Islam. Dari data demografis ini, umat Islam praktis menjadi umat mayoritas. Hanya saja, jumlah demografis yang besar ini belum diimbangi dengan kualitas yang memadai. Sebenarnya, piranti untuk meningkatkan kualitas masyarakat atau umat Islam adalah dengan cara membenahi dan meningkatkan mutu pendidikannya. Hanya saja, sekali lagi, lembaga-lembaga pendidikan Islam sebagian besar juga bermutu rendah. Berikut pandangan Buya Syafii tentang mayoritas tunakualitas

Sudah sejak lama kita merisaukan kesenjangan yang parah antara jumlah mayoritas umat Islam Indonesia dan kualitas kehidupan mereka yang tertinggal jauh dari buritan pada hamper semua bidang, khususnya di bidang ilmu, teknologi, dan ekonomi. Oleh karena itu, untuk melangkah ke depan masalah kualitas ini harus mendapatkan perhatian yang sungguh-sungguh dari para pemimpin Islam Indonesia agar kesenjangan itu secara berangsur dan sadar dapat dipertautkan. Posisi mayoritas tunakualitas akan

33 Ahmad Syafii Maarif. 1994. "Pendidikan Islam sebagai Paradigma Pembebasan" makalah disampaikan pada diskusi senat mahasiswa Fakultas Tarbiyah IAIN Sunan Kalijaga Yogyakarta tanggal 3 Nopember 1987. Kemudian, tanpa mengalami perubahan artikel ini dimuat dalam buku antologi Muslih Usa (Ed). 1991. Pendidikan Islam di Indonesia: Antara Cita dan Fakta. Yogyakarta: Tiara Wacana hlm. 17-26; dan Ahmad Syafii Maarif. 1994. Peta Bumi intelektualisme Islam di Indonesia. Bandung: Mizan, hlm. 144-148. 
menjadi beban Islam sebagai agama yang ingin membangun peradaban asri yang berkualitas tinggi.

Untuk masalah ini, faktor pendidikan, di samping faktor-faktor lain, akan sangat menentukan. Karena kelalaian kita untuk memikirkan masalah pendidikan ini secara bersungguh-sungguh, maka buahnya yang semakin mendera kita adalah ketertinggalan umat dalam bidang ilmu, teknologi, dan ekonomi ${ }^{34}$.

\section{Kemandekan intelektualisme Islam}

Seruan kaum modernis Islam untuk kembali kepada A-Qur'an dan Sunnah, sebagai sumber pokok ajaran Islam, ternyata belum mampu melahirkan pemikiran baru yang ontentik-produktif dan fungsional untuk memecahkan persoalan umat Islam. Gerakan modernis Islam baru mampu menelorkan intelektual pemamah yang mereproduksi pemikiran-pemikiran dari luar untuk dibawa masuk ke Indonesia. Ini artinya, pendaratan dan pembumian gerakan intelektualisme masih mengalami kemandekan.

Pendaratan secara intelektual dari slogan "kembali kepada Al-Quran dan Sunnah" dalam bentuk gagasan-gagasan dan teori pemikiran yang tajam dan utuh masih perlu kita galakkan pada masamasa mendatang di Indonesia. Selama tiga perempat abad sejak munculnya gerakan modern Islam kita baru menghasilkan pemikir pemamah sekalipun di antara mereka telah menghasilkan karya yang cukup banyak ${ }^{35}$.

Dari pengalaman empiris sejarah selama 14 abad kita memang dihadapkan kepada realitas-realitas kehidupan kolektif yang keras dan kadang-kadang sangat memprihatinkan. Maksudnya adalah bahwa

34 Ahmad Syafii Maarif. 2009. Islam dalam Bingkai Keindonesiaan dan Kemanusiaan: Sebuah Refleksi Sejarah. Bandung Mizan, hlm. 213. Buku ini sangat istimewa, karena ditulis secara utuh, bukan hanya kumpulan tulisan. Sementara buku-buku lain, diluar publikasi disertasi, tesis, dan skripsinya berasal dari arikel atau tulisan yang kemudian dikumpulkan menjadi suatu buku.

35 Ahmad Syafii Maarif. 1994. Peta Bumi...... hlm.117. dari sumber ajaran yang sama, ternyata telah melahirkan perbedaan-perbedaan pendapat di kalangan umat. Perbedaanperbedaan itu seakan-akan tidak mungkin didamaikan lagi karena telah begitu mengakar dalam larutan kultur umat Islam tertentu. Penafsiran Islam yang sudah larut inilah, kata sementara orang, yang tidak memungkinkan lagi kita menciptakan suatu tata kehidupan yang bersaudara dalam bentuk kesatuan umat, sebagaimana Nabi dan generasi awal telah meneladankannya. Anggapan ini adalah anggapan yang tidak mampu menempatkan Islam dalam perspektif sejarah ${ }^{36}$.

Demikianlah sketsa permasalahan pendidikan Islam yang mendasar menurut pandangan Buya Syafi. Perbincangan selanjutnya adalah menelusuri percikan pemikiran yang ditawarkan oleh Buya Syafii untuk memecah kebuntuan pendidikan Islam Indonesia, sebagaimana akan dibahas dalam uraian selanjutnya.

\section{Percikan Pemikiran Pendidikan Islam}

Bertitik tolak dari sketsa permasalahan pendidikan Islam sebagaimana dilukiskan di atas, Buya Syafii berusaha menggumuli masalah-masalah itu secara intens dan serius. Menghadapi dualisme dikotomi ilmu, ia menawarkan gagasan rekonstruksi filsafat dan tujuan pendidikan Islam; strategi mengangkat mutu pendidikan Islam sebagai upaya mengangkat kualitas pendidikan Islam, dan untuk mengikis kemandekan intelektualisme Islam, dia berupaya menciptakan iklim yang kondusif untuk pertumbuhan intelektualisme Islam yang otentik dan produktif.

Konsisten dengan percikan pemikirannya, sejauh ini hampir seluruh energi intelektualnya dikerahkan dan diivestasikan untuk menangani masalahmasalah kebangsaan, kemanusiaan, dan kemoderenan dengan jalan membangkitkan intelektualisme Islam. Dalam konteks pendidikan Islam, secara kasar percikan pemikirannya dapat dipilah menjadi tiga agenda, yaitu: (1) rekonstruksi filsafat 36 Ahmad Syafii Maarif. 1994. Peta Bumi ..... hlm. 44. 
dan tujuan pendidikan Islam; (2) strategi mengangkat mutu pendidikan Islam; dan (3) menggairahkan iklim intelektualisme Islam.

\section{Rekonstruksi filsafat dan tujuan pendidikan Islam}

Telah disinggung di atas, bahwa dualisme dikotomi ilmu dalam sistem pendidikan Islam yang kemudian merembet pada dualisme umat Islam dalam memandang kehidupan, bersumber dari kerapuhan fondasi filsafat pendidikan Islam dan diperparah oleh beban kesejarahan sebagai bangsa terjajah. Untuk keluar dari kemelut dualisme dikotomi ilmu, Buya Syafii tidak setuju dengan gagasan islamisasi ilmu, tetapi malah menawarkan jurus sendiri berupa perubahan paradigma filsafat pendidikan Islam yang berangkat dari etik Al-Qur'an dan prinsip kesatuan ilmu sebagai manifestasi Tauhid.

Untuk memahami lebih rinci argumentasi Buya Syafii tentang urgensi perubahan atau rekonstruksi filsafat pendidikan Islam, mari cermati kutipan berikut ini:

Tanpa kesediaan dan kesadaran yang mendalam akan perlunya merumuskan dan memahami filsafat pendidikan Islam yang baru secara sangat kasar diuraikan di atas, maka kaum Muslim yang bertebaran di muka bumi akan tetap saja mengembara tanpa peta yang jelas. Persis sebagaimana umat-umat lain yang tidak punya AlQur'an. Di sinilah tantangan terberat yang harus dicarikan solusinya oleh para pemikir Muslim yang punya kepedulian terhadap maha pentingnya perubahan paradigma filosofis dalam sistem pendidikan Islam ${ }^{37}$.

Cukup disayangkan, meskipun Buya Syafii berulangkali mengajak merumuskan ulang filsafat pendidikan Islam, namun sampai sedemikian jauh dia belum mencoba menuliskan secara ringkas sekalipun tentang formulasi atau rekonstruksi filsafat pendidikan yang diidealkannya.

37 Ahmad Syafii Maarif. 2009. Islam dalam Bingkai..... hlm. 230.
Berbeda dengan permasalahan filsafat, dalam masalah tujuan pendidikan, dia secara eksplisit menyebut tujuan pendidikan yang diimpikan. Sejurus dengan ajakan untuk melakukan perubahan paradigma filsafat pendidikan, maka tujuan pendidikan Islam pun perlu dirumuskan ulang. Out put pendidikan Islam harus mampu memahami bahasa langit sebagai pemandu atau pemberi arah dan petunjuk kehidupan di bumi.

Corak pendidikan yang diinginkan Islam ialah pendidikan yang mampu membentuk "manusia yang unggul secara intelektual, kaya dalam amal, serta anggun dalam moral dan kebajikan". Untuk meraih tujuan ini, diperlukan suatu landasan filosofis pendidikan yang sepenuhnya berangkat dari cita-cita Al-Qur'an tentang manusia $^{38}$.

Sekali lagi, cita-cita pendidikan Islam telah dirumuskan secara gamblang. Namun demikian, ketika bicara filsafat pendidikan Islam masih belum tergambarkan secara jelas. Hanya saja, dari rujukan yang dipakai, nampaknya Buya Syafii menginginkan filsafat pendidikan Islam berorientasi pada filsafat pendidikan kritis sebagaimana dirumuskan Paulo Freire, plus nilai-nilai Islam yang berangkat dari etika Al-Qur'an sebagai pemberi arahnya.

\section{Strategi meningkatkan kualitas pendidikan Islam}

Perhatian Buya Syafii terhadap peningkatan kualitas umat Islam demikian besar. Kuantitas banyak yang tidak diserati dengan kualitas malah menjadi beban sejarah, tidak terkecuali dengan kondisi Islam Indonesia. Pada titik inilah kita bisa memahami mengapa dia di banyak tulisannya mengajak untuk membenahi diri dan melakukan autokritik terhadap umat Islam, tidak terkecuali Muhammadiyah, persyarikatan yang pernah dipimpinnya. Masalah peningkatan kualitas adalah

38 Ahmad Syafii Maarif. 1994. Peta Bumi........, hlm. 154. 
masalah besar, untuk membenahinya Buya Syafii memberi saran atau kiat-kiat sebagai berikut.

Di antara masalah besar yang sedang kita hadapi sekarang ialah bagaimana menampilkan Muhammadiyah sebagai gerakan Islam yang benar-benar berorientasi pada kualitas yang handal. Dan kualitas itu menyangkut banyak aspek: aspek pemikiran, aspek amal usaha, aspek organisasi, dan yang tidak kalah pentingnya ialah aspek persaudaran yang harus terasa dalam gerak Muhammadiyah ${ }^{39}$.

Buya Syafii tidak hanya memberi arah perubahan kualitatif di tingkat makro keumatan, tetapi juga mencurahkan perhatian pada peningkatan mutu pendidikan Islam. Ia memberikan tiga kata kunci atau semacam resep jitu untuk memajukan lembaga pendidikan Islam. Ketiga resep itu ialah komitmen pada idealisme, sikap akomodatif dan fleksibel, dan terakhir membangun jamaah atau kebersamaan. Untuk memahmi lebih jelas kerangka pemikirannya, mari disimak uraiannya berikut ini.

Saya mengamati ada kekuatan tersirat yang melatarbelakangi amal usaha semacam itu (baca: SMK Muhammadiyah Gondanglegi Malang-pen). Pertama, jumlah kecil dengan kualitas yang tinggi dalam semangat, finansiil, komitmen kepada nilai-nilai idealisme, kekompakan dan nilai plus lainnya, punya peluang besar untuk memenangkan masa depan, kapan pun dimana pun. Kedua, sikap akomodatif dan fleksibel tapi tidak pernah menjual prinsip terhadap lingkungan: budaya, birokrasi, ekonomi merupakan cara yang layak dikembangkan dalam melakukan ekspansi gerakannya. Ketiga, koordinasi dari PDM kabupaten Malang terhadap beberapa Cabang Muhammadiyah yang potensial di daerah itu telah membuahkan hasil-hasil yang membanggakan ${ }^{40}$.

39 Ahmad Syafii Maarif. 2000. Independensi Muhammadiyah di Tengah Pergumulan Pemikiran Islam dan Politik. Jakarta: Cidesindo, hlm. 131.

40 Ahmad Syafii Maarif. 2000. Independensi Muhammadiyah ......., hlm. 125-126.
Dari kutipan di atas dapat dicatat bahwa kiat atau strategi meningkatkan kualitas lembaga pendidikan Islam, baik ditingkat perguruan tinggi maupun pendidikan dasar dan menengah adalah harus membangun tiga budaya sekaligus, yaitu: menjaga idealisme, bersikap fleksibel-akomodatif tapi tetap berpegang idealisme, dan membiasakan koordinasi, silaturahmi sebagai implementasi gerakan jamaah. Peningkatan mutu pendidikan Islam merupakan jalan lempang untuk memajukan kehidupan umat Islam dan bangsa Indonesia pada umumnya.

Menggairahkan iklim intelektualisme Islam

Perkembangan perguruan tinggi Islam, baik yang dikelola oleh pemerintah maupun swasta, secara kuantitatif mengalami pertumbuhan yang cepat. Namun demikian, pertumbuhan kuantitatif tersebut belum dibarengai dengan pembenahan kualitas, sehingga tujuan pendidikan Islam sebagai penyangga dan instrumen intelektualisme Islam masih jauh panggang dari api. Secara normatif, idealnya perguruan tinggi Islam bukan sekedar melahirkan out put yang mampu menghasilkan pekerja yang terampil-profesional, tetapi lebih dari itu, dapat menelorkan agar para pemikir Muslim yang mampu memecahkan persoalanpersoalan kemanusiaan kontemporer dengan cahaya etik al-Qur'an.

Dengan mengutip gurunya, Fazlur Rahman, Buya Syafii mengingatkan kembali fungsi perguruan tinggi Islam sebagai penelor intelektualisme Islam, bukan sekedar sebagai pekerja terampilprofesional.

Esensi pendidikan tinggi Islam, menurut Fazlur Rahman, tidak lain dari pada intelektualisme Islam dengan penafsiran Al-Quran yang benar dan tepat sebagai sentralnya...terobosan-terobosan pemikiran baik budaya maupun religius hanyalah mungkin dilakukanbila kita punya otoritas intelektual. Proses dekonstruksi dan rekonstruksi terhadap seluruh bingkai pemikiran Islam, klasik dan modern, tidak 
akan mencapai posisi yang berwibawa bila otoritas kita diragukan orang ${ }^{41}$.

\section{KESIMPULAN}

Berdasarkan seluruh uraian di atas dapat diketahui garis besar pemikiran pendidikan Islam Buya Syafii. Latar belakang akademiknya sebagai sejarawan melatihnya membaca situasi sosial secara realistis-kritis, sedangkan keahliannya dalam pemikiran Islam mendorongnya untuk mempertautkan setiap peristiwa sosio-historis di bawah cahaya etik AlQur'an. Pergumulan pemikiran Islam, demikian pula dimensi kependidikannya, bergerak secara dialektis antara idealitas Islam dengan realitas umat Islam sebagai jalan membangun peradaban utama yang mensejahterakan manusia di planet ini.

Kalau mencermati tokoh-tokoh yang dijadikan referensi utama Buya Syafii dalam membangun pemikiran pendidikannya terdapat nama-nama Muhammad Iqbal (Pakistan) dan Fazlur Rahman (PakistanAmerika), dan teoritikus pendidikan kritis asal Brasilia, Paulo Freire. Dari sumber referensi yang digunakan sudah tergambar corak pemikiran kependidikanya, yaitu pendidikan kritis-religius.

Permasalahan mendasar pendidikan Islam di Indonesia menurut optik Buya Syafii mencakup titik utama, yaitu permasalahan: (1) dualisme dikotomomi ilmu yang menempatkan ilmu agama lebih utama dibanding ilmu umum, padahal untuk mengeksplorasi alam dan mengelola bumi mempersyaratkan penguasaan ilmu umum; (2) secara umum kualitas lembaga pendidikan Islam rendah, sehingga belum mampumenghasilkanlulusan sesuaidengan

41 Ahmad Syafii Maarif. 2000. Independensi Muhammadiyah ......, hlm. 38-41. tujuan pendidikan Islam; (3) kemandekan intelektualisme atau pemikiran Islam yang berawal dari ditutupnya pintu ijtihad pada abad XIII.

Pemikiran pendidikan Islam Buya Syafii bertolak dari titik-titik permasalahan pendidikan umat Islam, seperti disinggung di atas, sebagai realitas sosial yang dihadapi. Sembari menatap realitas sosial pendidikan Islam, Buya Syafii mencoba mendialogkannya dengan Al-Quran sebagai sumber utama ajaran Islam. Pergumulan idealitas-realitas inilah yang kemudian melahirkan terobosan pemikiran baru pendidikan Islam.

Secara garis besar ada tiga jurus, yaitu: (1) melampaui dualisme dikotomi ilmu dengan jalan merekonstruksi filsafat dan tujuan pendidikan Islam; (2) jurus meningkatkan mutu pendidikan Islam dengan cara memupuk idealisme, kebersamaan atau berjamaah secara social, dan memperkuat komunikasi antara pengelola, penyelenggara, dan pemilik lembaga pendidikan; dan (3) menggairahkan intelektualisme Islam dengan jalan menata perguruan tinggi Islam yang berkualitas, sehingga tidak hanya mampu melahirkan kaum profesional terampil, tapi juga menghasilkan pemikir atau intelektualisme Islam yang membumi dan otentik yang bersedia bergumul dengan masalah-masalah sosial yang tumbuh di lingkungannya.

Demikianlah, penelitian baru menjajagi garis besar pemikiran pendidikan Islam Buya Syafii, yang bercorak kritis. Para peneliti berikutnya dapat menjabarkan lebih jauh bagaimana kompnen-komponen sistem pendidikan Islam, seperti konsep pendidik ataupun kurikulum pendidikan Islam menurut Buya Syafii.

\section{DAFTAR PUSTAKA}

Ali, Fachry \& Bahtiar Effendy. Merambah Jalan Baru Islam: Rekonstruksi Pemikiran Islam Indonesia Masa Orde Baru. Bandung: Mizan, 1986.

Azumardi Azra. “Islam Indonesia: Kontribusi kepada Peradaban Global”, dlm. Prisma Vol. 
29, Oktober, 2010.

Anwar, M. Syafii. Pemikiran dan Aksi Islam Indonesia. Jakarta: Paramadina, 1995

Effendy, Bahtiar. Islam dan Negara: Transformasi Pemikiran dan Praktik Politik Islam di Indonesia. Jakarta: Paramadina, 1998.

Boland, B. J. Pergumulan Islam di Indonesia 1945-1970. Terjemahan Saafroedin Bahar. Jakarta: Grafiti Pers, 1985.

Barton, Greg. Gagasan Islam Liberal di Indonesia. Terjemahan Nanang Tahqiq. Jakarta: Pustaka Antara-Paramadina, 1999.

Buchori, Mochtar. Spektrum Problematika Pendidikan di Indonesia. Yogyakarta: Tiara Wacana, 1994.

Crow and Crow. Pengantar Ilmu Pendidikan. Yogyakarta: Rake Sarasin, 1990.

Effendy, Bahtiar. Islam dan Negara: Transformasi Pemikiran dan Praktik Politik Islam di Indonesia. Jakarta: Paramadina, 1998.

Hassan, Muhammad Kamal. Modernisasi Indonesia: Respon Cendekiawan Muslim. Terjemahan Ahmadie Thaha. Jakarta: Lingkaran Studi Indonesia, 1987.

Karim, M. Rusli. Dinamika Islam di Indonesia: Suatu Tinjauan Sosial Politik. Yogyakarta: Hanindita, 1985.

Kaelan. Metode Penelitian Kualitatif bidang Filsafat. Yogyakarta: Paradigma, 2005.

Kartodirdjo, Sartono. “Metode Penggunaan Dokumen” dlm. Kuntjoroningrat (Ed.). Metode-Metode Penelitian Masyarakat .Jakarta: Gramedia, 1983.

Kuntowijoyo. Dinamika Umat Islam di Indonesia. Yogyakarta: Salahuddin Press \& Pustaka Pelajar, 1994.

Maarif, Ahmad Syafii. Islam dan Pancasila sebagai Dasar Negara. Jakarta: LP3ES, 2006.

-------------. Titik-titik Kisar di Perjalananku. Bandung: Mizan, 2009.

----------------- . Peta Bumi intelektualisme Islam di Indonesia. Bandung: Mizan, 1994.

. Independensi Muhammadiyah di Tengah Pergumulan Pemikiran Islam

dan Politik. Jakarta: Cidesindo, 2000.

.. Islam dalam Bingkai Keindonesiaan dan Kemanusiaan: Sebuah Refleksi

Sejarah. Bandung: Mizan, 2009.

Madjid, Nurcholish. "Islam in Indonesia: A Move from the Periphery to the Center" dlm. Kultur. Vol. 1/No. 1, 2000.

. Bilik-bilik Pesantren: Sebuah Potret Perjalanan. Jakarta: Paramadina, 1997.

Nata, Abuddin. Pemikiran Para Tokoh Pendidikan Islam. Jakarta: Rajawali Pers, 2003.

Tokoh-tokoh Pembaharuan Pendidikan Islam di Indonesia, Jakarta: Rajawali Pers, 2005.

Peacock, James L. Pembaharu dan Pembaharuan Agama. Terjemahan Muhadjir Darwin. Yogyakarta: Hanindita, 1983.

Rahman, Fazlur. Islam dan Modernitas: Tentang Transformasi Inteletual. Terjemahan Mohammad Ahsin. Bandung: Pustaka, 2005.

Smith. Islam dalam Sejarah Modern. Terjemahan Abusalamah. Jakarta: Bhratara, 1964.

Sukmadinata, Nana Syaodih. Metode Penelitian Pendidikan. Bandung: Rosdakarya, 2009.

Syamsuddin, Din. Islam dan Politik Era Orde Baru. Jakarta: Logos, 2001 
PROFETIKA, Jurnal Studi Islam, Vol. 17, No. 2, Desember 2016: 1-14

Thoyib, Ruswan \& Darmuin (Ed.). Pemikiran Pendidikan Islam: Kajian Tokoh Klasik dan Kontemporer. Yogyakarta: Pustaka Pelajar, 1999.

Usa, Muslih dan Aden Wijdan (Ed.), Pendidikan Islam dalam Peradaban Industrial. Yogyakarta: Aditya Media, 1999.

Usa, Muslih (Ed.). Pendidikan Islam di Indonesia: Antara Cita dan Fakta. Yogyakarta: Tiara Wacana, 1991.

Wahid, Abdurrahman. Menggerakkan Tradisi: Esai-esai Pesantren. Yogyakarta: LKiS, 2007. 